Discourse and Communication for Sustainable Education, vol. 9, no. 1, pp. 79-85, 2018

\title{
Teaching Sustainability in an Accounting Classroom
}

\author{
Timothy Creel and Veronica Paz \\ Harding University and Indiana University of Pennsylvania, \\ United States of America
}

\begin{abstract}
Sustainability has become an important issue in the world today for both business and society. As accounting faculty members, it is important that we add aspects of sustainability into accounting classrooms to help prepare students for what they will see in the workplace. The article aims to discuss areas for faculty to share with students the importance of sustainability. The methods of discussing sustainability in the classroom come from the teaching experiences of the authors. Cost, managerial, and intermediate accounting courses, as well as auditing at both the undergraduate and graduate levels, serve as conduits for sustainability concepts. Examples include discussing the triple bottom line, examining CSR reports and assurance services for them, talking about required environmental reporting and integrated reporting, and examining green balanced scorecards. The hope is that faculty can help students learn not only accounting but how to be better citizens with a global perspective on sustainability.

Keywords: sustainability, accounting, intermediate accounting, cost accounting, managerial accounting, auditing.
\end{abstract}

\section{Teaching Sustainability in an Accounting Classroom}

The environment and sustainability are important issues to society today. Not only is the environment an important consideration to our society, it is growing in its importance to business and the accounting profession as well. Businesses perform many positive functions toward the environment such as implementing recycling programs, reducing waste or using solar power in their locations.

With the emphasis on sustainability in the world today, it is important that it become a part of university curriculum (Biasuti, De Baz, \& Alshawa, 2016). As accounting professors, we want to best prepare our students for what they will witness in the workplace after graduation. With the growth of careers in sustainability accounting such as increases in integrated social and financial reporting (Rogers, 2016) and environmental auditing (O'Dwyer \& Owen, 2005), accounting faculty should incorporate sustainability into their classrooms to better prepare students for the future. Sharing sustainability 
in the classroom not only prepares them for the workplace but also prepares students to support a worldview of social responsibility (Bell, 2016).

The purpose of this writing is to illustrate the application and importance of incorporating sustainability concepts into university accounting classes. The article shares ideas on accounting topics related to sustainability and where they can be discussed in accounting classes. Educators may include examples of sustainability concepts as part of undergraduate and graduate courses in cost, managerial, and intermediate accounting along with auditing. The methods of building sustainability into accounting courses include discussions of accounting and auditing careers based on sustainability and examples of sustainability-related business operations and reporting practices.

\section{Background}

Sustainability is becoming a part of the strategy in business today. There has been a shift in recent years in business strategy towards involving sustainability for the benefit of their stakeholders (Klettner, Clarke, \& Boersma, 2014). It follows the stakeholder theory of business which states that companies serve different stakeholders both inside and outside the organization and maintaining their satisfaction is an important part of business success (Woller, 2007). Many companies practice sustainability to meet the needs of their stakeholders (Ballou, Heitger, \& Landes, 2006). Some customers enjoy doing business with companies that are friendly toward the environment. Sustainability also benefits a company with internal stakeholders as well as it has been shown to help a company recruit talented employees (McWilliams \& Siegel, 2001), improve employee job satisfaction (Edmans, 2011), increase employee retention rates (Moir, 2001), and enhance performance at work (Carmeli, Gilat, \& Waldman, 2007).

The benefits to a company for practicing sustainability are many. Companies that engage in sustainability practices can obtain financial benefits(Lev, Petrovits, \& Radhakrishnan, 2010), and enjoy enhancements to their reputation (Toms, 2002). Investors and stakeholders positively value Corporate Social Responsibility (CSR) including sustainability as it has a positive effect on company reputation and decreases thecost of capital (Martinez-Ferrero, Banerjee, \& Garcia-Sanchez, 2016). Organizations that practice sustainability may benefit from being involved in socially responsible investing by becoming part of mutual funds solely investing in socially and environmentally friendly companies (Holder-Webb, Cohen, Nath, \& Wood, 2009; Cohen, Holder-Webb, \& Khalil, 2015). Companies that report more transparent information related to CSR and sustainability have a higher level of corporate governance across the organization (Chan, Watson, \& Woodliff, 2013).

Many companies report their positive environmental actions in self-prepared CSR or sustainability reports. Some of these CSR reports follow set guidelines provided by the Global Reporting Initiative (GRI) and requires audits by outside third-parties. More than $90 \%$ of the largest 250 companies around the world produce CSR or sustainability reports and the majority of these follow the GRI guidelines (Boiral, Heras-Saizarbitoria, \& Brotherton, 2017). 


\section{Methodology}

The approaches applying sustainability concepts to accounting courses are from past teaching experiences from the authors regarding sustainability in accounting education. The limitations of this approach are there are no tests of their effectiveness other than their past successful use by the authors. The goal of the paper is to share ideas about the importance and how and where to present sustainability topics in an accounting classroom, but there may be different ways or areas that could be presented other than those discussed here by the authors.

\section{Cost and Managerial Accounting}

The largest area to promote sustainability concepts in an accounting classroom is cost and managerial accounting classes at both undergraduate and graduate levels. There are several ways to discuss it in relation to capital budgeting examples, the qualitative aspects of decision-making, ethics and case studies, green balanced scorecards, the triple bottom line, ISO 14000 environmental standards and life-cycle costing.

Capital budgeting involves examining investment decisions based on expected future financial results. Using an example of purchasing new equipment that is more energy efficient is an investment decision that can save money in the long-run as the savings represent future cash flows from the investment. Professors may use this example with net present value (NPV), internal rate of return (IRR), and payback. It also allows students to see that environmentally-sound decisions that promote sustainability can produce positive financial effects for an organization.

When teaching decision-making techniques such as make or buy decisions, special orders or dropping a segment or product, we examine the quantitative aspects of business decisions. Adding further discussion of the qualitative aspects of making business decisions adds a dimension to the learning experience of the students. For example, discussing why an environmentally friendly company may want to purchase a hybrid vehicle as a company car because it fits the image they wish to portray even though less expensive options may exist. This also adds to the entrepreneurial aspects of sustainability for those students who want to start their own business someday and illustrates the benefits of operating a small business with a positive approach to sustainability (Bikse, LusenaEzera, Riuza, \& Volkova, 2016; Iliško, 2016).

As is the case in most accounting classes, ethics are usually discussed in managerial and cost accounting classes. It is effective to mention cases such as the wreck of the Exxon Valdez and the BP oil spill in the Gulf of Mexico to illustrate the damage to a company's reputation that comes from being the cause of environmental disasters. Case studies allow students to see real-world examples of the positive effects of sustainability. Also, the Institute of Management Accountants (IMA) has an extensive library of case studies in sustainability for use in a classroom setting.

The Balanced Scorecard attempts to measure performance based on four aspects: financial, the customer, internal business processes, and learning and growth. It attempts to add a balanced approach to performance evaluation by examining aspects of the business beyond just the financials. Business initiatives may also use the Balanced Scorecard as a measurement tool. A company can develop a Green Balanced Scorecard to support an environmental initiative and measure the effectiveness of their performance. 
This illustration shows students how sustainability can benefit the stakeholders of a company.

Like the Balanced Scorecard, the Triple Bottom Line attempts to evaluate business performance based on measures outside of financial results. It examines business performance based on financial, social, and environmental results. This method of evaluation illustrates to students that social and environmental performance are just as important as financial results when evaluating business performance.

The International Organization for Standardization (ISO) has developed quality standards in Europe for many years. Companies can become certified based on following these standards and passing inspections from an outside third-party. The ISO 14000 standards developed around effective environmental management and performance improvements. Many companies will only do business with other organizations that meet the ISO standards. The ISO 14000 standards illustrate to students the benefits a business receives from maintaining high environmental standards.

\section{Intermediate Accounting}

Financial reporting is the area of intermediate accounting that addresses sustainability. Areas of financial reporting related to sustainability include the voluntary production of corporate social responsibility reports, environmental liabilities, and integrated reporting.

During intermediate accounting classes, it is a great idea to show students actual corporate financial statements. When examining actual financial statements, looking at voluntarily prepared corporate social responsibility (CSR) reports from companies such as Walmart or Apple shows students the positive, sustainable actions of some companies. It also illustrates to students the strong commitments many organizations have toward their communities, social causes, and the environment.

There is a growing need for accountants to be aware of environmental reporting requirements and environmental liabilities. As part of U.S. GAAP, FASB 5 defines and provides information on environmental liabilities recorded as a loss contingency. The discussion of these liabilities reflects the long-term goal of accounting for environmental costs and the effect of business operations on the environment.

Integrated reporting involves adding social performance reporting to current financial reporting and includes sustainability. Some countries already require integrated reporting, while in Europe it is growing in importance. Integrated reporting illustrates the value of sustainability performance within the financial results.

The Sustainability Accounting Standards Board is a private, non-profit organization that develops sustainability reporting standards. Its goal is to help promote sustainability performance transparency in areas related to financial performance and operational efficiency. Their role should grow in importance as companies believe sustainability positively affects the long-term performance of the organization and due to the expected future growth of integrated reporting (Rogers, 2016). 


\section{Auditing}

Along with managerial and intermediate accounting, auditing also offers an area to share sustainability in the classroom. Auditing courses can address assurance services related to an organization's sustainability performance.

With the growing numbers of companies preparing CSR or sustainability reports, auditing and reviewing these reports by providing sustainability assurance services is a possible area of growth for Big 4 and smaller accounting firms (O'Dwyer \& Owen, 2005). This could also be an area of career interest for students interested in promoting sustainability, the environment and greater global citizenship in business organizations.

\section{Conclusion}

There is a growing emphasis on sustainability in business today, and many companies include sustainability as part of their overall business strategy. Companies can benefit in many ways from including sustainability as a major part of the business including financial (Lev, Petrovits, \& Radhakrishnan, 2010), reputation enhancements (Toms, 2002), and improvements in stakeholder relations (Ballou, Heitger, \& Landes, 2006). Several organizations voluntarily prepare sustainability or CSR reports that detail their actions toward the environment and social actions. These actions can include everything from setting up recycling programs, improving efficiency to save energy, or using solar power for example.

Accounting faculty should find more ways to integrate sustainability into their curriculum and courses as this field continues to grow in importanceboth in the profession and in society. Educators may discuss sustainability in many areas of accounting including managerial or cost accounting, intermediate accounting, or auditing. Examples include using environmentally friendly examples in areas such as capital budgeting, discussing performance measures such as the Triple Bottom Line or the Green Balanced Scorecard, talking about social and integrated financial reporting, and mentioning careers in environmental auditing and audits of the company prepared sustainability or CSR reports.

As accounting professors, we should try to best prepare students for what they will see in the workplace, thereby showing students the importance of sustainability illustrates a greater worldview and global citizenship (Miedema \& Bertram-Troost, 2015). By teaching them the importance of sustainability, we not only teach them accounting but show them how to be responsible citizens and thrive in a more sustainable future economy (Bell, 2016).

Sustainability will continue to grow in importance in relation to the accounting profession and society. Future research opportunities related to accounting and sustainability could include more research on the financial and reputational benefits to companies that practice sustainability. Additional research could also be completed based on the benefits of including sustainability as part of university accounting and business programs. An example will be examining if students are more likely to take jobs with sustainabilityfriendly organizations after graduation from universities with a stronger emphasis on sustainability as part of their curriculum. 


\section{References}

Ballou, B., Heitger, D., Landes, C., \& Adams, M. (2006). The future of corporate sustainability reporting. Journal of Accountancy, 202, 65-74.

Bell, D. (2016). Twenty-first century education: Transformative education for sustainability and responsible citizenship. Journal of Teacher Education for Sustainability, $18,48-56$.

Biasutti, M., De Baz, T., \& Al Shawa, H. (2016). Assessing the infusion of sustainability principles into University Curricula. Journal of Teacher Education for Sustainability, $18,21-40$.

Bikse, V., Lusena-Ezera, I., Riuza, B., \& Volkova, T. (2016). The transformation of traditional universities into entrepreneurial universities to ensure sustainable higher education. Journal of Teacher Education for Sustainability, 18, 75-88.

Boiral, O., Heras-Saizarbitoria, I., \& Brotherton, M. (2017). Assessing and improving the quality of sustainability reports: The auditors' perspective. Journal of Business Ethics, March, 1-19.

Carmeli, A., Gilat, A., \& Waldman, D. (2007). The role of perceived organizational performance in organizational identification, adjustment, and job performance. Journal of Management Studies, 44, 972-992.

Chan, M., Watson, J., \& Woodliff, D. (2014). Corporate governance quality and CSR disclosures. Journal of Business Ethics, 125, 59-73.

Cohen, J., Holder-Webb, L., \& Khalil, S. (2015). A further examination of the impact of corporate social responsibility and governance on investment decisions. Journal of Business Ethics, November, 1-16.

Edmans, A. (2011). Does the stock market fully value intangibles? Employee satisfaction and equity prices. Journal of Financial Economics, 101, 621-640.

Holder-Webb, L., Cohen, J., Nath, L., \& Wood, D. (2009). The supply of corporate social responsibility disclosures among U.S. Firms. Journal of Business Ethics, 84, 497-527.

Iliško, Dz. (2016). Inquiry-based educational course in higher education towards sustainable communities: A case study. In Leal Filho W., Pace P. (Eds). Teaching Education for Sustainable Development at University Level. World Sustainability Series. Springer, Cham. doi: https://doi.org/10.1007/978-3-319-32928-4_9.

Klettner, A., Clarke, T., \& Boersma, M. (2014). The governance of corporate sustainability: Empirical insights into the development, leadership, and implementation of responsible business strategy. Journal of Business Ethics, 122, 145-165.

Lev, B., Petrovits, C., \& Radhakrishnan, S. (2010). Is doing good good for you? How corporate charitable contributions enhance revenue growth. Strategic Management Journal, 31, 182-200.

Martinez-Ferrero, J., Banerjee, S., \& Garcia-Sanchez, I. (2016). Corporate social responsibility as a strategic shield against costs of earnings management practices. Journal of Business Ethics, 133, 305-324.

McWilliams, A., \& Siegel, D. (2001). Corporate social responsibility: A theory of the T firm perspective. The Academy of Management Review, 26, 117-127.

Miedema, S., \& Bertram-Troost, G. (2015). The challenges of global citizenship for worldview education. The perspective of social sustainability. Journal of Teacher Education for Sustainability, 17, 44-52. 
Moir, L. (2001). What do we mean by corporate social responsibility? Corporate Governance, 1, 16-22.

O’Dwyer, B., \& Owen, D. (2005). Assurance statement practice in environmental, social, and sustainability reporting: A critical evaluation. The British Accounting Review, $37,205-229$.

Rogers, J. (2016). The next frontier: Measuring and managing sustainability performance. Strategic Finance, June, 28-37.

Toms, J. (2002). Firm resources, quality signals and the determinants of corporate environmental reputation: Some UK Evidence. The British Accounting Review, 34, $257-$ 282.

Woller, G. (2007). Trade-offs between social \& financial performance. ESR Review, Fall, 14-19.

Correspondence concerning this paper should be addressed toVeronica Paz, Indiana University of Pennsylvania. Email: Veronica.paz@iup.edu 